\title{
Detection of piscine nodaviruses by real-time nucleic acid sequence based amplification (NASBA)
}

\author{
William G. Starkey*, Rose Mary Millar, Mary E. Jenkins, Jacqueline H. Ireland, \\ K. Fiona Muir, Randolph H. Richards
}

Department of Virology, Institute of Aquaculture, University of Stirling, Stirling FK9 4LA, UK

\begin{abstract}
Nucleic acid sequence based amplification (NASBA) is an isothermal nucleic acid amplification procedure based on target-specific primers and probes, and the co-ordinated activity of 3 enzymes: AMV reverse transcriptase, RNase H, and T7 RNA polymerase. We have developed a real-time NASBA procedure for detection of piscine nodaviruses, which have emerged as major pathogens of marine fish. Viral RNA was isolated by guanidine thiocyanate lysis followed by purification on silica particles. Primers were designed to target sequences in the nodavirus capsid protein gene, yielding an amplification product of 120 nucleotides. Amplification products were detected in real-time with a molecular beacon (FAM labelled/methyl-red quenched) that recognised an internal region of the target amplicon. Amplification and detection were performed at $41^{\circ} \mathrm{C}$ for $90 \mathrm{~min}$ in a Corbett Research Rotorgene. Based on the detection of cell culture-derived nodavirus, and a synthetic RNA target, the real-time NASBA procedure was approximately 100-fold more sensitive than single-tube RT-PCR. When used to test a panel of 37 clinical samples (negative, $\mathrm{n}=18$; positive, $\mathrm{n}=$ 19), the real-time NASBA assay correctly identified all 18 negative and 19 positive samples. In comparison, the RT-PCR procedure identified all 18 negative samples, but only 16 of the positive samples. These results suggest that real-time NASBA may represent a sensitive and specific diagnostic procedure for piscine nodaviruses.
\end{abstract}

KEY WORDS: Nodavirus $\cdot$ NASBA $\cdot$ RT-PCR $\cdot$ Diagnostics $\cdot$ Nucleic acid amplification Resale or republication not permitted without written consent of the publisher

\section{INTRODUCTION}

Betanodaviruses are the aetiological agents of viral nervous necrosis (VNN), also referred to as vacuolating encephalopathy and retinopathy, or fish encephalopathy (Mori et al. 1992, Comps et al. 1994). Since the first description of VNN in Martinique (Bellance \& Gallet de Saint Aurin 1988), this disease has occurred in more than 30 species of fish in Europe, Asia, Australia, and Japan (Munday \& Nakai 1997, Munday et al. 2002). Recently, betanodavirus infections have been reported in the UK (Starkey et al. 2000, 2001) and North America (Curtis et al. 2001, Barker et al. 2002).

The betanodavirus genome is comprised of 2 segments of single stranded, positive polarity RNA.
The RNA 1 segment of striped jack nervous necrosis virus (SJNNV) is 3107 bases long (Iwamoto et al. 2001), and encodes a non-structural protein of $110 \mathrm{kD}$ (Nagai \& Nishizawa 1999). RNA 2 is 1421 bases long (Iwamoto et al. 2001), and encodes the $42 \mathrm{kD}$ coat protein precursor (Mori et al. 1992). Betanodaviruses can be classified into 4 genotypes, based on the nucleotide sequence of the coat protein gene (Nishizawa et al. 1997). Recently, a nodavirus with distinct genomic sequence was isolated from sea bass Dicentrarchus labrax in France (Thiéry et al. 1999).

Betanodavirus infections represent a serious economic threat to the aquaculture industry. Rapid and sensitive diagnostic assays for nodaviruses are required to identify outbreaks of infection and for the screening of broodstock fish for virus carriage. Molec- 
ular diagnostic methods based on RT-PCR (Nishizawa et al. 1994, Grotmol et al. 2000) or nested RT-PCR (Dalla Valle et al. 2000) have been developed for betanodaviruses, and have contributed significantly to the diagnosis and control of VNN. However, these assays are relatively time-consuming, may be compromised by limited sensitivity, and are susceptible to false positive reactions arising from amplicon contamination.

Nucleic acid sequence based amplification (NASBA) (Compton 1991) is an isothermal method for nucleic acid amplification that is particularly suited to RNA targets (Kievits et al. 1991). Diagnostic procedures based on NASBA methodology have been described for several viruses including Human Immunodeficiency Virus Type 1 (de Baar et al. 1999), cytomegalovirus (Witt et al. 2000), enterovirus (Heim \& Schumann 2002), West-Nile and St Louis Encephalitis viruses (Lanciotti \& Kerst 2001), parainfluenza virus (Hibbitts et al. 2003) and hepatitis C virus (Damen et al. 1999). In the NASBA procedure, target-specific amplification is achieved through oligonucleotide primers and the co-ordinated activity of 3 enzymes: reverse transcriptase, RNase $\mathrm{H}$, and T7 RNA polymerase. The final amplification product is a singlestranded RNA, the polarity of which is opposite to that of the target. Real-time detection in NASBA can be performed using molecular beacons, which are incorporated directly into amplification reactions (Leone et al. 1998). Molecular beacons are oligonucleotide probes that form a stem-loop structure (Tyagi \& Kramer 1996). The loop contains a probe sequence that recognises the target amplicon. The stem is formed by the annealing of complementary sequences situated at each end of the probe. A fluorescent reporter is covalently linked to the $5^{\prime}$ end of the probe, and a quencher is covalently linked to the $3^{\prime}$ end. In the absence of target amplicon, the fluorophore and quencher are held in close proximity so that the fluorescence of the reporter is quenched. In the presence of target amplicon, the probe will hybridise and shift into an open configuration, separating the reporter and quencher. The resulting increase in fluorescence can be monitored in amplification reactions in real time. During this procedure, the assay tube remains sealed, minimising risks of false positive results arising from amplicon contamination.

In the present study we report on the development of a real-time NASBA procedure for detection of betanodaviruses. The sensitivity of this assay was compared to a conventional single-tube RT-PCR assay for betanodaviruses. To our knowledge, this is the first use of the NASBA procedure for diagnosis of an aquatic pathogen.

\section{MATERIALS AND METHODS}

Clinical samples. A panel of 37 clinical samples submitted to the Institute of Aquaculture virology laboratory was utilised in this study. The panel included samples from sea bass Dicentrarchus labrax, brownspotted grouper Epinephelus malabaricus, striped jack Pseudocaranx dentex, rock porgy Oplegnathus punctatus and Atlantic cod Gadus morhua. The origin of the samples is indicated in Table 1. Samples were classified as nodavirus positive or negative on the basis of clinical signs, histopathology, virus isolation in cell culture and serum neutralisation, as described previously (Office International des Epizooties 1995, Frerichs et al. 1996).

Virus isolation. Brain tissues were dissected under aseptic conditions, and homogenised at a dilution of 1:50 w/v in Hank's Balanced Salt Solution (HBSS) containing $2 \%$ Foetal Bovine Serum (FBS). Homogenates were filtered through $0.45 \mu \mathrm{m}$ filters prior to storage at $-70^{\circ} \mathrm{C}$.

Virus propagation. Betanodavirus preparations were prepared by growth in SSN-1 cells (derived from striped snakehead Channa striatus) as described by Frerichs et al. (1996). The infectious titre of virus preparations was determined using the method of Spearman-Karber (Hamilton et al. 1977).

Synthetic RNA transcript. A synthetic RNA transcript corresponding to nucleotides 293 to 1030 of the RNA 2 genome segment of a sea bass nodavirus isolate was prepared using a RT-PCR-derived template and a commercial kit (Megascript-T3, Ambion), according to the manufacturer's instructions. The nucleotide sequence of the nodavirus RNA 2 segment used to produce the synthetic transcript is available in GenBank (AF175512). The transcript was analysed by gel electrophoresis and the concentration determined by UV spectrophotometry.

RT-PCR. Conventional RT-PCR amplifications were performed using the Ready-to-Go kit (Pharmacia). The reaction buffer contained $10 \mathrm{mM}$ Tris- $\mathrm{HCl}(\mathrm{pH} 9.0)$, $60 \mathrm{mM} \mathrm{KCl}, 1.5 \mathrm{mM} \mathrm{MgCl}_{2}, 200 \mu \mathrm{M}$ of each dNTP, and porcine ribonuclease inhibitor. Upstream (CGTGTCAGTCATGTGTCGCT) and downstream (CGAGTCAACACGGGTGAAGA) oligonucleotide primers (Nishizawa et al. 1994) were complementary to nucleotides 604 to 623 and 1011 to 1030 of the nodavirus RNA 2 segment. Reverse transcription and thermal cycling were performed at $42^{\circ} \mathrm{C}$ for $30 \mathrm{~min}, 95^{\circ} \mathrm{C}$ for $5 \mathrm{~min}$, followed by 32 cycles of $95^{\circ} \mathrm{C}$ for $1 \mathrm{~min}, 55^{\circ} \mathrm{C}$ for $1 \mathrm{~min}$ and $72^{\circ} \mathrm{C}$ for $1 \mathrm{~min}$, then finally $72^{\circ} \mathrm{C}$ for $5 \mathrm{~min}$. Amplification products were analysed in $1 \%$ agarose gels, stained with ethidium bromide and visualised under UV illumination.

RNA isolation. Tissue homogenates prepared as described above for virus isolation were used for viral RNA isolation. NASBA isolation reagents (Nuclisens ${ }^{\circledR}$ 
Table 1. Comparison of real-time nucleic acid sequence based amplification (NASBA) and RT-PCR for detection of betanodaviruses in a panel of 37 clinical samples classified as positive (+ve) or negative (-ve) on the basis of virus isolation in cell culture. In 'Culture' column, results are of virus isolation on SSN-1 cell monolayers. In the 'NASBA-Tp' column, real-time NASBA results are expressed as time to positivity ( $T p$ ) in minutes (see 'Materials and methods'). Interpretation is of of real-time NASBA Tp value (see 'Materials and methods')

\begin{tabular}{|c|c|c|c|c|c|c|}
\hline Sample & Species & Origin & Culture & RT-PCR & NASBA-Tp & Interpretation \\
\hline 1 & Dicentrarchus labrax & Malta & $-\mathrm{ve}$ & $-\mathrm{ve}$ & $>90$ & $-\mathrm{ve}$ \\
\hline 2 & D. labrax & Malta & - ve & - ve & $>90$ & $-\mathrm{ve}$ \\
\hline 3 & D. labrax & Malta & + ve & + ve & 30.1 & $+\mathrm{ve}$ \\
\hline 4 & Gadus morhua & UK & + ve & + ve & 49.5 & $+\mathrm{ve}$ \\
\hline 5 & D. labrax & Malta & +ve & +ve & 29.9 & $+\mathrm{ve}$ \\
\hline 6 & Oplegnathus punctatus & Japan & +ve & - ve & 30.9 & +ve \\
\hline 7 & O. punctatus & Japan & +ve & - ve & 27.1 & +ve \\
\hline 8 & D. labrax & Malta & +ve & +ve & 67.4 & +ve \\
\hline 9 & Epinephelus malabaricus & Thailand & $+\mathrm{ve}$ & +ve & 29.4 & +ve \\
\hline 10 & D. labrax & Malta & $+\mathrm{ve}^{\mathrm{a}}$ & +ve & 72.3 & +ve \\
\hline 11 & D. labrax & Italy & $+\mathrm{ve}$ & +ve & 30.8 & +ve \\
\hline 12 & D. labrax & Italy & $+\mathrm{ve}$ & +ve & 29.5 & +ve \\
\hline 13 & D. labrax & Malta & - ve & $-\mathrm{ve}$ & $>90$ & $-\mathrm{ve}$ \\
\hline 14 & D. labrax & Italy & +ve & - ve & 45.3 & $+\mathrm{ve}$ \\
\hline 15 & D. labrax & Malta & +ve & $+\mathrm{ve}$ & 52.3 & $+\mathrm{ve}$ \\
\hline 16 & D. labrax & Greece & $+\mathrm{ve}$ & $+\mathrm{ve}$ & 34.7 & $+\mathrm{ve}$ \\
\hline 17 & D. labrax & Malta & $+\mathrm{ve}^{\mathrm{a}}$ & $+\mathrm{ve}$ & 40.4 & $+\mathrm{ve}$ \\
\hline 18 & D. labrax & Malta & $-\mathrm{ve}$ & $-\mathrm{ve}$ & $>90$ & $-\mathrm{ve}$ \\
\hline 19 & D. labrax & Malta & -ve & -ve & $>90$ & $-\mathrm{ve}$ \\
\hline 20 & D. labrax & Malta & -ve & $-\mathrm{ve}$ & $>90$ & $-\mathrm{ve}$ \\
\hline 21 & D. labrax & Malta & $-\mathrm{ve}$ & $-\mathrm{ve}$ & $>90$ & $-\mathrm{ve}$ \\
\hline 22 & D. labrax & Malta & +ve & +ve & 41.1 & $+\mathrm{ve}$ \\
\hline 23 & D. labrax & Malta & +ve & +ve & 36.6 & $+\mathrm{ve}$ \\
\hline 24 & D. labrax & Malta & +ve & +ve & 34.7 & +ve \\
\hline 25 & D. labrax & Spain & $+\mathrm{ve}$ & $+\mathrm{ve}$ & 38.1 & +ve \\
\hline 26 & D. labrax & Malta & - ve & $-\mathrm{ve}$ & $>90$ & $-\mathrm{ve}$ \\
\hline 27 & D. labrax & Malta & - ve & $-\mathrm{ve}$ & $>90$ & $-\mathrm{ve}$ \\
\hline 28 & D. labrax & Malta & - ve & -ve & $>90$ & $-\mathrm{ve}$ \\
\hline 29 & D. labrax & Malta & - ve & $-\mathrm{ve}$ & $>90$ & $-\mathrm{ve}$ \\
\hline 30 & D. labrax & Malta & $-\mathrm{ve}$ & $-\mathrm{ve}$ & $>90$ & $-\mathrm{ve}$ \\
\hline 31 & D. labrax & Malta & $-\mathrm{ve}$ & $-\mathrm{ve}$ & $>90$ & $-\mathrm{ve}$ \\
\hline 32 & D. labrax & Malta & $-\mathrm{ve}$ & -ve & $>90$ & $-\mathrm{ve}$ \\
\hline 33 & D. labrax & Malta & $-\mathrm{ve}$ & -ve & $>90$ & $-\mathrm{ve}$ \\
\hline 34 & Pseudocaranx dentex & Japan & +ve & +ve & 30.2 & +ve \\
\hline 35 & D. labrax & Malta & $-\mathrm{ve}$ & -ve & $>90$ & $-\mathrm{ve}$ \\
\hline 36 & D. labrax & Malta & $-\mathrm{ve}$ & $-\mathrm{ve}$ & $>90$ & $-\mathrm{ve}$ \\
\hline 37 & D. labrax & Malta & $-\mathrm{ve}$ & - ve & $>90$ & $-\mathrm{ve}$ \\
\hline
\end{tabular}

lysis buffer and isolation reagents) were obtained from bioMérieux. RNA isolation was performed using a modification of the method described by Boom et al. (1990). A total of $100 \mu \mathrm{l}$ of sample was added to $900 \mu \mathrm{l}$ of lysis buffer (5.0 M guanidine thiocyanate, $50 \mathrm{mM}$ Tris, 20 mM EDTA, 1.6\% w/v Triton X-100 pH 6.4, then vortexed prior to addition of $50 \mu \mathrm{l}$ silica suspension at $1 \mathrm{mg} \mathrm{ml}^{-1}$ ). Samples were incubated at room temperature for $10 \mathrm{~min}$, centrifuged, and then washed twice in wash-buffer (5.0 M guanidine thiocyanate, $50 \mathrm{mM}$ Tris, 20 mM EDTA, pH 6.4), twice in $70 \%$ ethanol, and then once in acetone. Pellets were air-dried at $56^{\circ} \mathrm{C}$ for $10 \mathrm{~min}$. RNA was eluted in $50 \mu \mathrm{l}$ of elution buffer (1 mM Tris $\mathrm{pH} 8.5$ ) at $56^{\circ} \mathrm{C}$ for $10 \mathrm{~min}$. RNA extracts were stored at $-70^{\circ} \mathrm{C}$.
NASBA oligonucleotide primers. Primers were synthesised by MWG Biotech and were designed to amplify a $120 \mathrm{bp}$ region of the nodavirus RNA 2 gene segment. Primers were designed on the basis of an alignment of 16 betanodavirus RNA2 sequences deposited in GenBank: AF175511, AF175518, AB045980, D38527, AF245004, AF175514, AF175512, AF175513, AF175515, D38636, AF245003, AF175516, AF175509, AF175510, AF175517, and U39876. In order to maximise sequence homology to the different nodavirus isolates, the primers were degenerate at 3 positions upstream and 1 position downstream. The downstream primer also contained a $5^{\prime}$ modification corresponding to a T7 RNA polymerase promoter, followed by a $6 \mathrm{bp}$ purinerich linker segment to facilitate efficient amplification. 
Upstream primer:

5'-GAARCAYTGGAGTTYGAAGTTCA-3'

Downstream primer:

5'-AATTCTAATACGACTCACTATAGGGAGAAGGAGTYGCTTGAAGCGCGTCGA-3'

$$
(\mathrm{R}=\mathrm{A} / \mathrm{G}, \mathrm{Y}=\mathrm{C} / \mathrm{T})
$$

The T7 polymerase promoter sequence in the downstream primer is underlined, and the purine-rich linker sequence is depicted in bold type.

Molecular beacon. The molecular beacon probe was synthesised by Oswel Research products. The beacon was designed to be complementary to a 20 bp internal region of the amplification product, and was synthesised with a 5' carboxyfluorescein (FAM) fluorophore label as reporter, and a 3' methyl-red modification as quencher. The predicted secondary structure of the probe was analysed using the Mfold 3.1 algorithm (Zuker 2003). This program is available at: www. bioinfo.rpi.edu/applications/mfold/old/dna/. The nucleotide sequence of the molecular beacon is shown below, and the secondary structure is shown in Fig. 1.

5'-FAM-CATGCGGATCCAACTGACAACGAYCACGCATG-Methyl red-3'

$$
(\mathrm{Y}=\mathrm{C} / \mathrm{T})
$$

The complementary 5'- and 3'-arm sequences are underlined.

Real-time NASBA amplification. Nucleic acid amplification was performed using the Nuclisens ${ }^{\circledR}$ Basic Kit amplification reagents (bioMérieux) according to the manufacturer's instructions. Briefly, $5 \mu \mathrm{l}$ of sample RNA extract was mixed with $10 \mu \mathrm{l}$ amplification mix $(1 \times$ reagent sphere, $80 \mu$ sphere-diluent, $14 \mu \mathrm{l}$ $\mathrm{KCl}, 10.6 \mu \mathrm{l} \mathrm{H}_{2} \mathrm{O}, 5 \mu \mathrm{l}$ upstream and downstream primers [10 $\mu \mathrm{M}$ stock], $5.4 \mu \mathrm{l}$ molecular beacon [12.31 $\mu \mathrm{M}$ stock]). The mixture was heated to $65^{\circ} \mathrm{C}$ for $5 \mathrm{~min}$ then cooled to $41^{\circ} \mathrm{C}$ for $5 \mathrm{~min}$ prior to addition of $5 \mu \mathrm{l}$ enzyme mix (avian myeloblastosis virus reverse transcriptase [6.4 U], RNase H [0.08 U], T7 RNA polymerase) (32 U). Amplification was performed at $41^{\circ} \mathrm{C}$ for $90 \mathrm{~min}$ in a Rotorgene (Corbett Research). Amplification was monitored in real-time using an excitation wavelength of $470 \mathrm{~nm}$ and fluorescent detection at $510 \mathrm{~nm}$ on Channel I of the Rotorgene. Fluorescent data were collected at intervals of $100 \mathrm{~s}$. Samples were classified as positive or negative using a modification of the criteria described by Lanciotti \& Kerst (2001). This was based on the time (time to positivity, Tp) at which sample fluorescence increased above a threshold value. The threshold was positioned above the background fluorescence value of notemplate-control samples, such that it intersected the

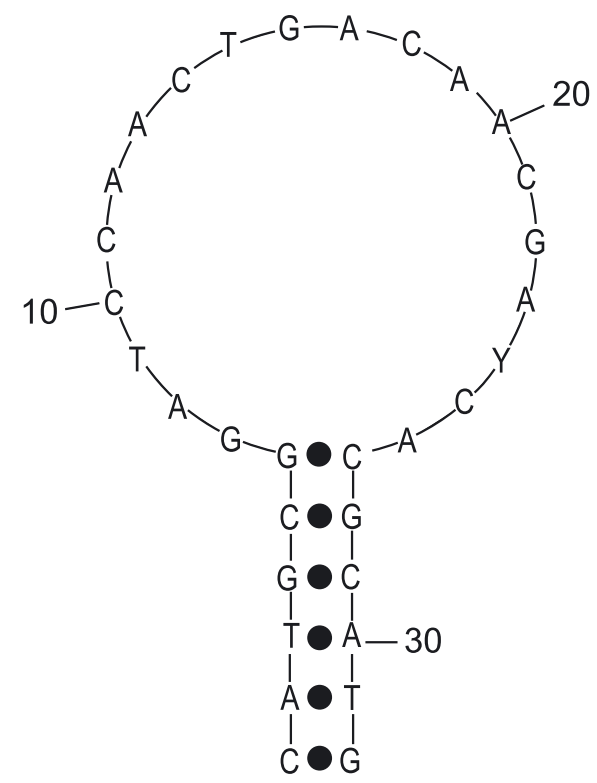

Fig. 1. Molecular beacon used for betanodavirus detection. The figure shows the nucleotide sequence and predicted secondary structure in the absence of target amplicon as analysed with Mfold 3.1 (Zuker 2003). The C residue at Position 1 was labelled with FAM (5-carboxyfluorescein), and the $\mathrm{G}$ residue at Position 32 carried a methyl-red modification as a quencher

exponential part of amplification reactions. On this basis, a threshold of 0.1 was used in all experiments. $T p$ values were expressed in minutes. Samples with $T p$ values $\leq 90$ min were considered positive.

\section{RESULTS}

\section{Nodavirus real-time NASBA assay: sensitivity and reproducibility}

The sensitivity of the nodavirus real time NASBA was estimated by determining the ability of the assay to amplify a dilution series of a sea bass nodavirus isolate propagated in cell culture, and a synthetic transcript corresponding to nucleotides 293 to 1030 of the nodavirus RNA 2 . The detection limit of the real-time NASBA assay was between 1.0 and $0.1 \mathrm{TCID}_{50}$ (Fig. 2) and between $10^{3}$ and $10^{2}$ copies of synthetic RNA transcript (Fig. 3). In comparison, the detection limit for the conventional RT-PCR assay was between 100 and 10 TCID $_{50}$ (Fig. 4) and $10^{5}$ and $10^{4}$ copies of synthetic transcript (data not shown).

The intra-assay reproducibility of the real-time NASBA assay was estimated by testing in replicate ( $n$ = 7) a sample of RNA extracted from a sea bass nodavirus isolate. The Tp value of this sample was 27.2. The standard deviation was 2.0 , and the coefficient of variation was $7.35 \%$. 


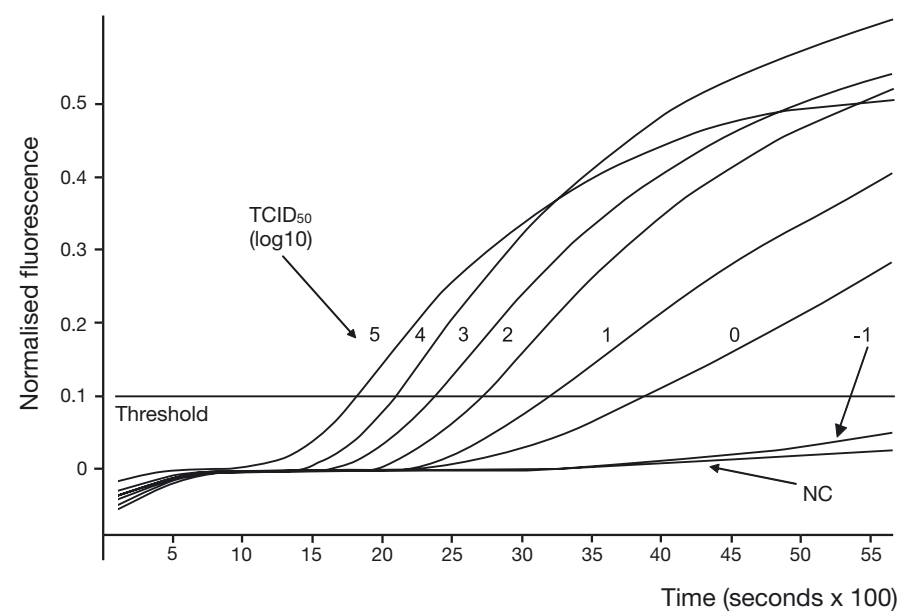

Fig. 2. Real-time nucleic acid sequence based amplification (NASBA) amplification of a dilution series of a sea bass nodavirus isolate. Amplification and detection were performed as described in 'Materials and methods'. Input target copies tested were: $\left(\log _{10} \mathrm{TCID}_{50}\right) 5,4,3,2,1,0,-1 . \mathrm{NC}=$ negative control. $y$-axis $=$ normalised fluorescence, $x$-axis $=$ time $(\mathrm{s})$

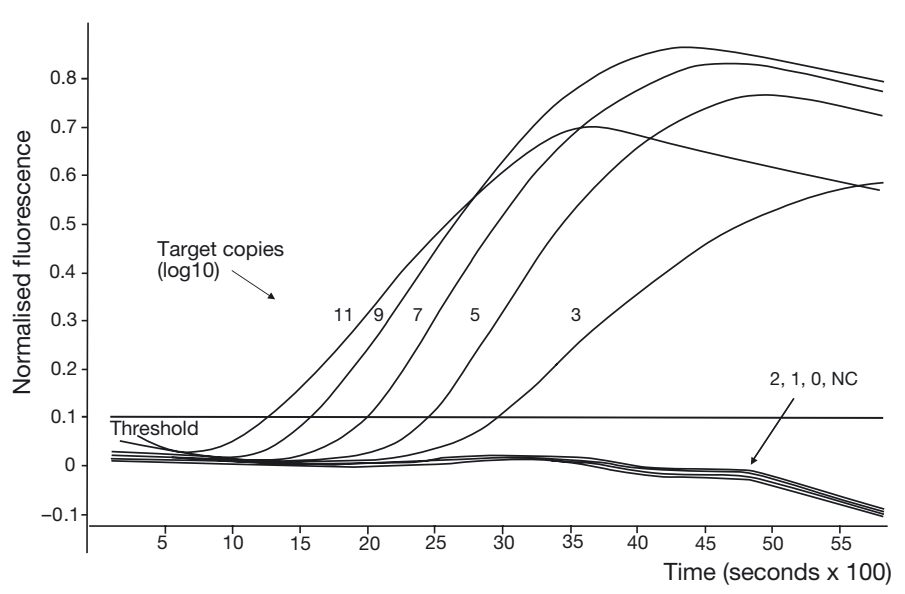

Fig. 3. Real-time nucleic acid sequence based amplification (NASBA) amplification of a dilution series of a synthetic transcript corresponding to nucleotides 293 to 1030 of the nodavirus RNA2 genome segment. Amplification and detection were performed as described in 'Materials and methods'. Input RNA copies tested were: $\left(\log _{10}\right): 11,9,7,5,3,2,1,0$. $\mathrm{NC}=$ negative control. $y$-axis $=$ normalised fluorescence, $x$-axis $=$ time $(s)$

\section{Real-time NASBA detection of nodaviruses in clinical samples}

A panel of 37 clinical samples classified as nodavirus infected $(n=19)$ or non-infected $(n=18)$, as described in 'Materials and methods', was studied using the real time NASBA assay. A representative experiment showing 8 positive samples and 2 negative samples is

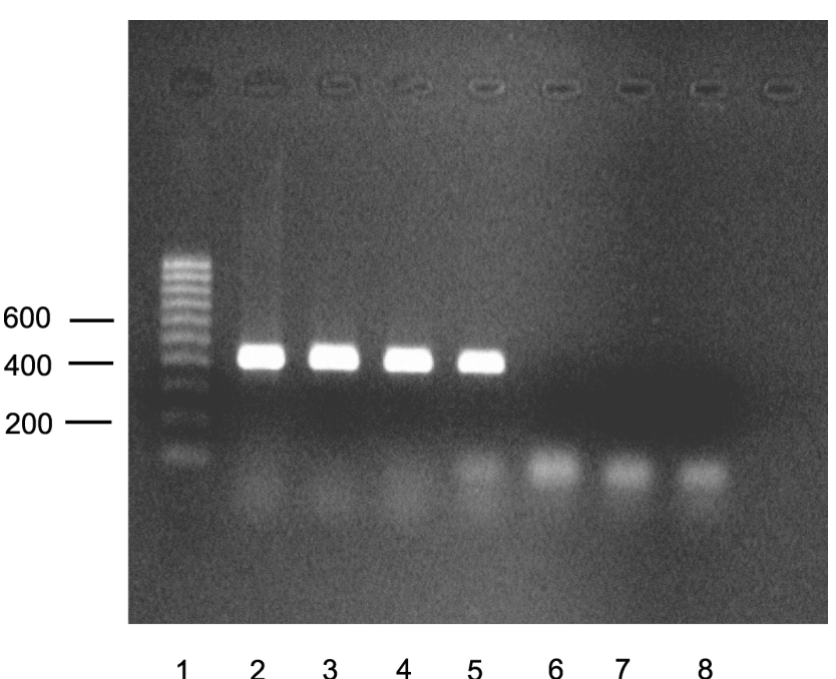

Fig. 4. RT-PCR amplification of a dilution series of a sea bass nodavirus isolate. Amplification and detection were performed as described in 'Materials and methods'. Amplification products were analysed on a $1 \%$ agarose gel visualised under UV illumination. Lane 1, markers, 1000 bp ladder in 100 bp increments; Lane 2: $10^{5}$ tissue culture infective dose $\left(\mathrm{TCID}_{50}\right)$; Lane 3: $10^{4} \mathrm{TCID}_{50}$; Lane 4: $10^{3} \mathrm{TCID}_{50}$; Lane 5: $10^{2} \mathrm{TCID}_{50}$; Lane 6: $10^{1} \mathrm{TCID}_{50}$; Lane $7: 10^{0} \mathrm{TCID}_{50}$; Lane 8: negative control

shown in Fig. 5, and the results for all 37 samples are summarised in Table 1. The real-time NASBA assay correctly identified 19 positive samples, and 18 negatives. The majority of positive samples yielded positive fluorescent signals in less than $60 \mathrm{~min}$. In comparison, the conventional RT-PCR assay identified only 16 of the positive samples (Table 1). Two NASBA-positive samples (\#10 and \#17) were not classified as nodavirus-positive by virus isolation on SSN-1 cell monolayers. However, on subsequent 'blind' passage on SSN-1 cells, these 2 samples produced cytopathic effects characteristic of nodavirus.

\section{DISCUSSION}

In this study we have developed a real-time NASBA procedure for the detection of betanodaviruses. Based on the use of cell-culture grown nodavirus and synthetic RNA targets, the assay was approximately 100fold more sensitive than conventional RT-PCR, and enabled detection of nodaviruses in clinical material isolated from sea bass, grouper, Atlantic cod, striped jack, and rock porgy. The detection limit of the realtime NASBA assay was between 1.0 and 0.1 TCID $_{50}$ or between $10^{3}$ and $10^{2}$ copies of synthetic RNA target. Other studies employing this technique have reported lower detection limits of between 100 and 10 copies of 


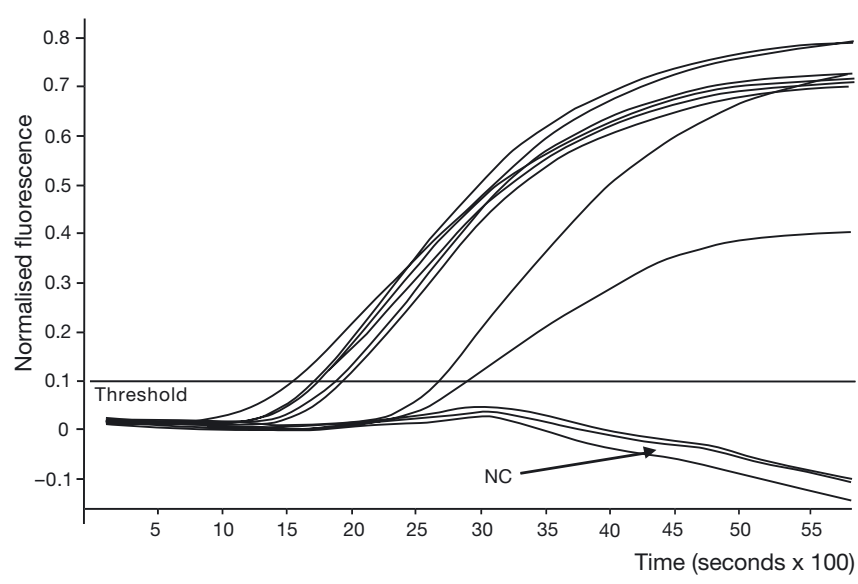

Fig. 5. Real-time nucleic acid sequence based amplification (NASBA) amplification of 10 clinical samples. Amplification and detection were performed as described in 'Materials and methods' $. \mathrm{NC}=$ negative control. $y$-axis $=$ normalised fluorescence, $x$-axis $=$ time $(s)$

viral RNA (Polstra et al. 2002). The reduced assay sensitivity found in the present study may be a result of the degenerate primers and probe used for amplification and detection of betanodaviruses, which exhibit considerable nucleotide sequence variation.

When used to detect nodaviruses in a panel of clinical samples, the real-time NASBA assay was more sensitive than conventional RT-PCR. Real-time NASBA correctly identified 19 positive samples, whereas RTPCR erroneously classified 3 nodavirus-infected samples as negative. Whilst these results are encouraging, an evaluation of the performance of the real-time NASBA assay based on analysis of greater numbers of clinical samples is required prior to routine use of this procedure for diagnosis of betanodavirus infection in fish.

The performance of the primers used in the real-time NASBA procedure was not investigated in RT-PCR. Thus it is possible that the observed difference in sensitivity between the real-time NASBA and RT-PCR assays was a result of differences in amplification efficiency of the primers used in each procedure. However, both assays were performed using primer pairs that were designed to optimise the efficiency of their respective amplification chemistry. Furthermore, our results are in agreement with other studies that have found NASBA to be of greater sensitivity than RT-PCR (Birch et al. 2001, Jean et al. 2001, Wacharapluesadee \& Hemachudha 2001).

NASBA offers a number of advantages as compared to RT-PCR. The NASBA assay is simple, rapid, and does not require the use of hazardous chemicals such as ethidium bromide for analysis of amplification reactions. In real-time NASBA, the use of molecular beacons permits simultaneous amplification and detection in 'closed-tube' format, minimising the risks associated with amplicon contamination. When coupled with RNA isolation on activated silica (Boom et al. 1990), NASBA appears to be less susceptible to inhibitory factors than RT-PCR (Witt \& Kemper 1999). NASBA is performed at lower temperatures than PCR, permitting amplification of targets that do not exactly match primer sequences. Real-time NASBA can be also be used to obtain quantitative data, and will be of use in studies of nodavirus pathogenesis, diagnostics, and also for environmental monitoring.

In the present study, whilst results of the NASBA assay and virus isolation were in close agreement, 2 samples classified as positive by the real-time NASBA assay were negative on initial cell-culture isolation on SSN-1 cell monolayers. However, on subsequent blind passage, these samples yielded cytopathic effects characteristic of nodavirus (Frerichs et al. 1996). This may be due to the presence of a very low concentration of virus in the 2 samples that was insufficient to produce cytopathic effects on initial culture. This observation suggests that the real-time NASBA assay may be of greater sensitivity than virus isolation in cell culture. Although cell-culture isolation methods can theoretically detect one infectious unit, the number of viral RNA copies in a sample always exceeds the number of infectious virus particles. Viral particle to infectivity ratios greater than 1000:1 have been reported (Cann 2001). Consequently, nucleic acid amplification procedures such as NASBA are potentially more sensitive than virus isolation in cell culture. The infectious titre in cell culture of clinical samples may also be affected adversely by sub-optimal collection, transport, or storage. Greater sensitivity of real-time NASBA as compared to virus isolation in cell culture has also been reported for Parainfluenza Virus Type 1 (Hibbitts et al. 2003) and St Louis encephalitis virus (Lanciotti \& Kerst 2001).

The oligonucleotide primers used in the present study were designed empirically, and thus may not be optimal for detection of betanodaviruses. Whilst the primers used were capable of detecting betanodaviruses isolated from diverse species of marine fish, we were unable to detect a nodavirus (TPNNV) isolated from tiger puffer Takifugu rubripes (data not shown). This may be a result of the genomic sequence variation exhibited by betanodaviruses and consequent failure of the primers or probe to recognise target sequences in the TPNNV genome. NASBA primers are relatively complex. The first 10 nucleotides following the T7 promoter sequence in the downstream primer should be purine-rich, and the 3' terminal residues of both primers ideally should be an adenosine. In the present study, to facilitate efficient amplification, 6 extra purine residues were incorporated in the downstream 
primer ahead of the target-specific sequence. The development of computer algorithms for design of NASBA-compatible primers based on nucleotide sequence alignments would greatly simplify the development of NASBA assays for aquatic viruses.

In summary, we have developed a real-time NASBA assay for detection of fish nodaviruses. Real-time detection was achieved through the use of a targetspecific molecular beacon. The assay was rapid, sensitive and specific, and was capable of detecting nodaviruses in clinical samples taken from several species of marine fish. The closed-tube format of the assay minimises the potential for amplicon contamination. Real-time NASBA may represent a useful molecular tool for the diagnosis of betanodavirus infection in marine fish, and for the study of betanodavirus pathogenesis and epidemiology.

Acknowledgements. This study was funded by award FAIRPL98-4036 from the European Union Framework 4 programme. We are grateful to T. Good and P. van Aarle of bioMérieux, for assistance in the development of NASBA methodology. The tiger puffer nodavirus was kindly provided by Professor T. Nakai, Hiroshima University, Japan.

\section{LITERATURE CITED}

Barker DE, MacKinnon AM, Boston L, Burt MDB and 6 others (2002) First report of piscine nodavirus infecting wild winter flounder Pleuronectes americanus in Passamaquoddy Bay, New Brunswick, Canada. Dis Aquat Org 49:99-105

Bellance R, Gallet de Saint Aurin D (1988) L'encephalite virale du loup de mer. Caraib Med 105:144

Birch L, Dawson CE, Cornett JH, Keer JT (2001) A comparison of nucleic acid amplification techniques for the assessment of bacterial viability. Lett Appl Microbiol 33 296-301

Boom R, Sol CJA, Salimans MM, Jansen CL, Wertheim van Dillen PM, van der Noordaa J (1990) Rapid and simple method for purification of nucleic acids. J Clin Microbiol 28:495-503

Cann AJ (2001) Principles of molecular virology, 3rd edn. Academic Press, London

Comps M, Pepin JF, Bonami JR (1994) Purification and characterization of two fish encephalitis viruses infecting Lates calcarifer and Dicentrarchus labrax. Aquaculture 123: $1-10$

Compton J (1991) Nucleic acid sequence based amplification. Nature 350:91-92

Curtis, PA, Drawbridge M, Iwamoto T, Nakai T, Hendrick RP, Gendron AP (2001) Nodavirus infection of juvenile white sea bass, Atractoscion nobilis, cultured in southern California: first record of viral nervous necrosis (VNN) in North America. J Fish Dis 24:263-271

Dalla Valle L, Zanella L, Patarnello P, Paolucci L, Belvedere P, Colombo L (2000) Development of a sensitive diagnostic assay for fish nervous necrosis virus based on RT-PCR plus nested PCR. J Fish Dis 23:321-328

Damen M, Sillekins P, Cuypers HTM, Frantzen I, Melsert R (1999) Characterization of the quantitative HCV NASBA assay. J Virol Methods 82:45-54 de Baar MP, van der schoot AM, Goudsmit J, Jacobs F and 5 others (1999) Design and evaluation of a human immunodeficiency virus type 1 RNA assay using nucleic acid sequence based amplification technology able to quantify both group $\mathrm{M}$ and $\mathrm{O}$ viruses by using the long terminal repeat as target. J Clin Microbiol 37:1813-1818

Frerichs GN, Rodger HD, Peric Z (1996) Cell culture isolation of piscine neuropathy nodavirus from juvenile sea bass, Dicentrarchus labrax. J Gen Microbiol 77:2067-2071

Grotmol S, Nerland AH, Beering E, Totland GK, Nishizawa T (2000) Characterisation of the capsid protein gene from a nodavirus strain affecting the Atlantic halibut Hippoglossus hippoglossus and design of an optimal RT-PCR (RTPCR) detection assay. Dis Aquat Org 39:79-88

Hamilton MA, Russo RC, Thurston RV (1977) Trimmed Spearman-Karber method for estimating median lethal concentrations in toxicity bioassays. Environ Sci Technol 11: $714-719$

Heim A, Schumann J (2002) Development and evaluation of a nucleic acid sequence based amplification protocol for the detection of enterovirus RNA in cerebrospinal fluid samples. J Virol Methods 103:101-107

Hibbitts S, Rahman A, John R, Westmoreland D, Fox JD (2003) Development and evaluation of Nuclisens basic Kit NASBA for diagnosis of parainfluenza virus infection with end point and real time detection. J Virol Methods 108: 145-155

Iwamoto T, Mise K, Mori K, Aromoto A, Nakai T, Okuno T (2001) Establishment of an infectious RNA transcription system for striped jack nervous necrosis virus, the type species of the betanodaviruses. J Gen Virol 82:2653-2662

Jean J, Blais B, Darveau A, Fliss I (2001) Detection of hepatitis $A$ virus by the nucleic acid sequence based ampification technique and comparison with reverse transcriptionPCR. Appl Environ Microbiol 67:5593-5600

Kievits T, van Gemen B, van Strijp D, Schukkink R and 5 others (1991) NASBA isothermal enzymatic in vitro nucleic acids amplification optimised for the diagnosis of HIV-1 infection. J Virol Methods 35:273-286

Lanciotti RS, Kerst AJ (2001) Nucleic acid sequence based amplification assays for rapid detection of West Nile and St Louis encephalitis viruses. J Clin Microbiol 39: $4506-4513$

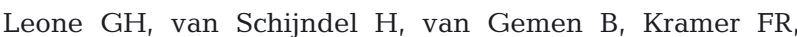
Schoen CD (1998) Molecular beacon probes combined with amplification by NASBA enables homogenous real time detection of RNA. Nucleic Acids Res 26:2150-2155

Mori K, Nakai T, Muroga K, Arimoto M, Mushiake K Furusawa I (1992) Properties of a new virus belonging to Nodaviridae found in larval striped jack (Pseudocaranx dentex) with nervous necrosis. Virology 187:368-371

Munday BL, Nakai T (1997) Nodaviruses as pathogens in larval and juvenile marine finfish. World J Microbiol Biotechnol 13:375-381

Munday BL, Kwang J, Moody N (2002) Betanodavirus infections of teleost fish: a review. J Fish Dis 25:127-142

Nagai T, Nishizawa T (1999) Sequence of the non-structural protein gene encoded by RNA1 of striped jack nervous necrosis virus. J Gen Virol 80:3019-3022

Nishizawa T, Mori K, Nakai T, Furusawa I, Muroga K (1994) Polymerase chain reaction (PCR) amplification of RNA of striped jack nervous necrosis virus (SJNNV). Dis Aquat Org 18:103-107

Nishizawa T, Furuhashi M, Nagai T, Nakai T, Muroga $K$ (1997) Genomic classification of fish nodaviruses by molecular phylogenetic analysis of the coat protein gene. Appl Environ Microbiol 63:1633-1636 
Office International des Epizooties (OIE) (1995) Viral encephalopathy and retinopathy. In: Diagnostic manual for aquatic animal diseases. OIE, Paris

Polstra AM, Goudsmitt J, Corneelissen M (2002) Development of real time NASBA assays with molecular beacon detection to quantify mRNA coding for HHV-8 lytic and latent genes. BMC Infect Dis 2:18

Starkey WG, Ireland JH, Muir KF, Shinn AP, Richards RH, Ferguson HW (2000) Isolation of nodavirus from Scottish farmed halibut, Hippoglossus hippoglossus. J Fish Dis 23: 419-423

Starkey WG, Ireland JH, Muir KF, Jenkins ME, Richards RH, Ferguson HW (2001) Nodavirus infection of cod and Dover sole in the United Kingdom. Vet Rec 149:179-181

Thiéry R, Arnauld C, Delsert C (1999) Two isolates of sea bass, Dicentrarchus labrax L., nervous necrosis virus with distinct genomes. J Fish Dis 22:201-207

Editorial responsibility: Carey Cunningham, Aberdeen, UK
Tyagi S, Kramer R (1996) Molecular beacons: probes that fluoresce upon hybridization. Nature Biotechnol 14: 303-308

Wacharapluesadee S, Hemachudha T (2001) Nucleic acid sequence based amplification in the rapid diagnosis of rabies. Lancet 358 892-893

Witt DJ, Kemper M (1999) Techniques for the evaluation of nucleic acid amplification technology performance with specimens containing interfering substances: efficacy of Boom methodology for extraction of HIV-1 RNA. J Virol Methods 79:97-111

Witt DJ, Kemper M, Stead A, Sillekins P and 6 others (2000) Analytical performance and clinical utility of a nucleic acid sequence-based amplification assay for detection of cytomegalovirus infection. J Clin Microbiol 38:3994-3999

Zuker M (2003) Mfold web server for nucleic acid folding and hybridization prediction. Nucleic Acids Res 31:3406-3415

Submitted: June 2, 2003; Accepted: November 12, 2003 Proofs received from author(s): April 24, 2004 